\title{
Effect of Feeding Amaranth on Growth Efficiency and Health of Market Pigs
}

\author{
Z. ZRALÝ, B. PÍSAŘÍKOVÁ, H. HUDCOVÁ, M. TRČKOVÁ, I. HERZIG \\ Veterinary Research Institute, Brno, Czech Republic \\ Received March 4, 2004 \\ Accepted October 26, 2004
}

Abstract

Zralý Z., B. Písaříková, H. Hudcová, M. Trčková, I. Herzig: Effect of Feeding Amaranth on Growth Efficiency and Health of Market Pigs. Acta Vet Brno 2004, 73: 437-444.

The aim of the study was to verify the effect of three diets containing $10 \%$ amaranth fed to pigs, on selected parameters of metabolism and health and on the growth efficiency in comparison with the control diet containing animal protein. The animals of each group were given the same diet during the entire period of fattening. Experimental and control groups of pigs $(n=10$ in each; 5 males +5 females) with live weight of $18 \mathrm{~kg}$ were partially ad libitum fed diets containing dried surface amaranth biomass or amaranth grain either non-heat-treated or heat-treated by popping, or a diet containing meat-and-bone meal for 100 days. No significant differences in the live body weight gains were detected between experimental and control groups. The highest daily body weight gain was recorded in animals fed the mixture containing heat-treated amaranth $(0.78 \mathrm{~kg})$ and the best feed conversion was detected in the group fed non-heat-treated grain $(2.45 \mathrm{~kg})$. The values of selected biochemical parameters ranged within the physiological limits.

Animal protein, performance, feed conversion, metabolism, health status

Occurrence of bovine spongiform encephalopathy (BSE), adopted measures directed against its spreading and EU requirements to ensure food safety (Anonymous 2000a) resulted in a complete prohibition of meat-and-bone meals (MBM) in the nutrition of all farm animal species. Subsequently, particular measures were introduced to enhance the confidence of consumers in the safety of food of animal origin and to minimize expected adverse effects of animal protein absence in the diets on the health status and growth efficiency of fattened monogastric animal categories.

After MBM prohibition, concern has been expressed what substances to use to replace of high-quality raw material previously used for preparation of feed mixtures. The diets must be supplemented with feeds which can saturate nitrogenous substances, essential amino acids and provide sufficient energy. The use of synthetic amino acids may create a problem as some of the trade chains refuse to sell food from animals fed diets containing them (Herzig 2001).

Although it is very difficult to replace animal protein, nevertheless leguminous plants (soy, pea and lupine), oil plants (oilseed rape and sunflower) and products of fat manufacture may be considered (Herzig 2001). All of the mentioned raw materials have certain limitations for feeding purposes. The use of soy is limited by the price and moreover, heat treatment is necessary for inactivation of antinutrient substances. Some types of soy also contain oestrogen-like substances (S ommer 2003). Extruded oilseed rape meal despite of decreased contents of glukosinolates and erucic acid, represent a factor that causes a significant decrease in iodine utilization with consequent signs of its deficiency found both in animals and animal products intended for human consumption (Herzig et al. 2001).

Address for correspondence

MVDr. Zdeněk Zralý, CSc.

Veterinary Research Institite

62132 Brno, Czech Republic

Phone: +420533331612

Fax: +420541211229

, zttp://www.vri.cz

(1) Brno, Czech Republic

http:/www. vfu.cz/acta-vet/actavet.htm 
One sustainable approach to reduce adverse effects of animal protein elimination from animal feed rations is the use of amaranth that meets the requirements of a substitute for the MBM (Herzig 2001).

Amaranthus (L.) genus comprises more than 60 species. Under the conditions of the Czech Republic, three following species are significant: A. caudatus, A. cruentus and $A$. hypochondriacus. Agrotechnical preconditions for its cultivation in our region have been well recognized (Jarošová et al. 1997).

Amaranth grain, dried green amaranth biomass (12 to $18 \%$ of $\mathrm{N}$-substances), liquid product "amaranth milk" (20 to $25 \% \mathrm{~N}$-substances) which can be condensed or powdered are considered as raw materials suitable for animal feeding. Grains contain a relatively high proportion of fat (6 to $8 \%$ ), crude fibre represents 3 to $5 \%$ and the composition of amino acids is better balanced than in conventional cereals (Carlsson 1979; Bressani et al. 1987; Szelényi-Galántai and Zsolnai-Harszi 1992; Andrasofszky et al. 1998).

It was confirmed in animal experiments that amaranth contains a high-quality protein (Imeri et al. 1987). However, in certain cases, the parameters of growth efficiency obtained were lower than expected (Correa et al. 1986). The possibility to use autoclaved grain for chickens was tested by Acar et al. (1988), the effects of extruded amaranth grain in feed rations were investigated by Tillman and W ald roup (1987) and nutritional quality of the surface biomass was studied in lambs by Pond and Lehmann (1989). However, available literature data on amaranth use in pig nutrition are missing.

The purpose of the present study was to ascertain whether it is possible to substitute MBM in a pig diet with amaranth when one type feed ration is used during the entire period of fattening and its impact on the growth efficiency and health of pigs.

\section{Materials and Methods}

Forty Large White $\times$ Landrace pigs in equal numbers of barrows and gilts (mean live weight $18.0 \pm 1.70 \mathrm{~kg}$ ) were used. All animals were earmarked by tattooing. Experimental animals were housed in pens of 10 pigs each, under good hygienic conditions of accredited animal facilities in the Veterinary Research Institute (approved project of the experiment No. 598 Ministry of Agriculture of the Czech Republic). Average surface apace was $1.7 \mathrm{~m}^{2}$ and the length of the feeding place was $0.3 \mathrm{~m}$ per pig. Straw was used as bedding. Conditions of animal hygiene were monitored by continuous measurements of ambient temperature and relative humidity.

The animals were weighed upon their arrival from the Agricultural Cooperative Farm and then 5 days after the end of the adaptation period. The experiment was preceded by an 11-day pre-treatment period, during which the pigs gradually adapted to the new diet and environment and concurrently, their performance and growth uniformity were monitored. They were preventively dewormed during that period with the doses according to the manufacturer's instructions (Ivomec, inj.; MSD, Agvet, USA).

Before biological testing commenced, the animals were weighed, and based on individual live weight, they were allocated to four groups ( 5 males and 5 females in each). Average weight of pigs in respective groups ranged between $17.8 \pm 1.8$ and $18.3 \pm 1.8 \mathrm{~kg}$. Variation coefficient $(<10 \%)$ was consistent with the requirements of biological testing (Anony mous 2000b).

Experimental diets were based on cereals (wheat and barley) and comprised extracted soy meal, $46 \%$ crude protein $(\mathrm{CP})$ and feed supplements. Control group diet $(\mathrm{C})$ contained $4 \%$ of meat-and-bone meal. The diets for three experimental groups contained $10 \%$ amaranth in the form of either dried surface amaranth biomass (DAB), or ground amaranth grain (GAG), or popped (heat-treated) amaranth grain (PAG).

Compositions of experimental diets are given in Table 1. The diets were suggested for fattening of meat type pigs with $56 \%$ proportion of lean musculature. The diets were analysed for the contents of basic nutrients (Anonymous 1996).

The diets were mixed with drinking water 1:1 and offered to each group of pigs twice a day during the experimental period (100 days), partially ad libitum. The amounts of feed were regulated according to the current intake and the weight of the animals so that food refusals might have been low. Thirty minutes after the beginning of feeding, the refusals were removed, weighed and taken into account in subsequent calculations. Water was available ad libitum.

Individually identified pigs were weighed at the beginning of the trial and on days 30,60, and 100 of the trial. The weighing precision was $0.1 \mathrm{~kg}$. Pigs were regularly weighed $2 \mathrm{~h}$ post feeding with the same succession of groups. The health status of animals was checked daily by observation at regular intervals. Occasional morbidity and mortality were recorded. Postmortem examination was performed in dead animals. 
At the beginning and end of the trial (day 100), always $3 \mathrm{~h}$ post feeding, blood samples were drawn from $v$. cava cranialis for biochemical evaluation. Total protein, albumin, glucose, triglycerids, total cholesterol, HDL and LDL cholesterol, alkaline phosphatase (ALP, EC 3.1.3.1), transferases (AST, EC 2.6.1.1; ALT, EC 2.6.1.2), calcium, phosphorus and magnesium blood plasma levels were determined. Spectrophotometric measurements using BioLa-Tests (PLIVA - Lachema Brno a.s., Czech Republic) were performed.

Individual and group weight gains during the experimental periods were calculated. Relative growth rate (q) of animals was determined according to the following formula (Karakoz 1968).

$$
\mathrm{q}=\frac{\mathrm{yt}-\mathrm{yo}}{\mathrm{yo}} \times 100
$$

yo $=$ weight at the beginning

$\mathrm{yt}=$ weight in a particular period

Feed conversion was calculated from feed consumption and live weight gains.

The results obtained were processed by statistical methods using statistical and graphic software STAT Plus (Matoušková et al. 1992).

\section{Results}

Appropriate diet for each animal group for both pre-treatment and trial periods was designed (Table 1). The content of $\mathrm{N}$-substances in the diets designated C, DAB, GAG and PAG was 183.2, 172.4, 173.8, and $173.2{\mathrm{~g} . \mathrm{kg}^{-1}}^{-}$, respectively. Metabolizable energy (MEp) ranged between 13.1 and $13.4 \mathrm{MJ}_{\mathrm{kg}}{ }^{-1}$. The ratio between lysin and MEp ranged between 0.814 and 0.831 g. $\mathrm{MJ}^{-1}$. Table 2 shows the content of the other nutrients.

Table 1

Composition of the diets

\begin{tabular}{|c|c|c|c|c|}
\hline \multirow{2}{*}{$\begin{array}{l}\text { Ingredients } \\
(\%)\end{array}$} & \multicolumn{3}{|c|}{ Diet $^{1}$} & \multirow[b]{2}{*}{ PAC } \\
\hline & $\mathrm{C}$ & DAB & GAG & \\
\hline Barley & 20.40 & 17.00 & 30.00 & 33.00 \\
\hline Wheat & 55.00 & 48.05 & 38.55 & 35.85 \\
\hline Extracted soy meal $46 \% \mathrm{CP}$ & 18.20 & 20.50 & 18.50 & 18.20 \\
\hline Meat and bone meal & 4.00 & - & - & - \\
\hline Amaranth & - & 10.00 & 10.00 & 10.00 \\
\hline Rapeseed oil & - & 2.00 & - & - \\
\hline Salt & - & 0.05 & 0.05 & 0.05 \\
\hline Ground limestone & - & - & 0.50 & 0.50 \\
\hline Monocalcium phosphate & 0.20 & 0.20 & 0.20 & 0.20 \\
\hline Unimak P1-M ${ }^{2}$ & 2.20 & 2.20 & 2.20 & 2.20 \\
\hline Total & 100 & 100 & 100 & 100 \\
\hline
\end{tabular}

1) $\mathrm{C}-$ control diet

DAB - dried surface amaranth biomass

GAG - ground amaranth grain

PAG - popped amaranth grain

2) Commercial supplement contained the following per kg: $335000 \mathrm{IU}$ vitamin $\mathrm{A}, 45000 \mathrm{IU}$ vitamin $\mathrm{D}, 125 \mathrm{mg}$ vitamin $\mathrm{K}, 2665 \mathrm{mg}$ vitamin $\mathrm{E}, 5.3 \mathrm{mg}$ vitamin $\mathrm{B}_{1}, 165 \mathrm{mg}$ vitamin $\mathrm{B}_{2}, 14 \mathrm{mg}$ vitamin $\mathrm{B}_{6}, 1.10 \mathrm{mg}$ vitamin $\mathrm{B}_{12}$, $165 \mathrm{mg}$ niacin, $250 \mathrm{mg}$ pant. calcium, $1000 \mathrm{mg}$ cholinchlorid, $0.8 \mathrm{mg}$ biotin, $6600 \mathrm{mg}$ vitamin C, $110 \mathrm{~g} \mathrm{~L}-\mathrm{lysine}$

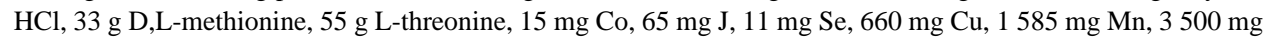
Zn, 2080 mg Fe, 56 g Na, 12 g Mg, 80 g P, 205 g Ca, 833 mg Endox, 11250 mg Bio-plus 2B,

$2900 \mathrm{mg}$ Natuphos 5 000G, $665 \mathrm{mg}$ Sacharin

Mean live weight of the pigs was $14.9 \pm 1.6 \mathrm{~kg}$ at the beginning and $18.04 \pm 1.7 \mathrm{~kg}$ at the end of the 11-day pre-treatment period. Mean weight gain during that period was $3.14 \pm 0.35$ $\mathrm{kg}$. Between-group differences in the mean weight of pigs either at the beginning of the experiment or in the subsequent experimental periods (day 30,60, and 100) were not 
Table 2

Nutrient contents in the diets

\begin{tabular}{|c|c|c|c|c|}
\hline \multirow{2}{*}{$\begin{array}{l}\text { Ingredients } \\
\left(\mathrm{g} \cdot \mathrm{kg}^{-1}\right)\end{array}$} & \multicolumn{3}{|c|}{ Diet $^{1}$} & \multirow[b]{2}{*}{ PAG } \\
\hline & $\mathrm{C}$ & DAB & GAG & \\
\hline Dry matter & 913.7 & 908.6 & 908.7 & 905.0 \\
\hline Nitrogenous substances & 183.2 & 172.4 & 173.8 & 173.2 \\
\hline Fat & 28.0 & 27.7 & 19.7 & 20.0 \\
\hline Fibre & 32.5 & 42.5 & 31.1 & 31.6 \\
\hline Ash & 96.4 & 59.2 & 57.2 & 53.4 \\
\hline Total & 340.1 & 301.8 & 281.8 & 278.2 \\
\hline $\mathrm{N}-\mathrm{FE}$ & 573.6 & 606.8 & 626.9 & 626.8 \\
\hline OM & 817.3 & 849.4 & 851.5 & 851.6 \\
\hline MEp $\quad\left(\mathrm{MJ}_{\mathrm{kg}} \mathrm{kg}^{-1}\right)$ & 13.1 & 13.2 & 13.4 & 13.3 \\
\hline Lysine $/ \mathrm{MEp}\left(\mathrm{g} \cdot \mathrm{MJ}^{-1}\right)$ & 0.814 & 0.830 & 0.831 & 0.829 \\
\hline
\end{tabular}

N-FE- nitrogen-free extracts

OM-organic matter

MEp-metabolizable energy

1) $\mathrm{C}$ - control diet

DAB - dried surface amaranth biomass

GAG - ground amaranth grain

PAG - popped amaranth grain

significant $(P>0.05)$. Table 3 shows that the highest weight gain was recorded between days 1 and 30 in the group DAB (index 102.4); between days 31 and 60 in pigs fed the diet with popped amaranth (index 102.2) and between days 61 and 100 in group GAG (index 105.8\%). Maximum relative growth rate was reached in group PAG $(437.8 \pm 65.9 \%)$, although the between-group difference was not significant (Fig. 1). Mean daily weight gains during the entire trial period for groups C, DAB, GAG, and PAG were 775, 763, 770, and $778 \mathrm{~g}$, respectively.

Table 3

Growth performance of pigs fed different diets $(\mathrm{kg})$

\begin{tabular}{|c|c|c|c|c|c|c|c|c|c|}
\hline & \multicolumn{2}{|c|}{$\begin{array}{c}\text { Live } \\
\text { weight }\end{array}$} & $\begin{array}{c}\text { Weight } \\
\text { gain }\end{array}$ & $\begin{array}{c}\text { Live } \\
\text { weight }\end{array}$ & $\begin{array}{l}\text { Weight } \\
\text { gain }\end{array}$ & $\begin{array}{c}\text { Weight } \\
\text { gain }\end{array}$ & $\begin{array}{c}\text { Live } \\
\text { weight }\end{array}$ & $\begin{array}{l}\text { Weight } \\
\text { gain }\end{array}$ & $\begin{array}{c}\text { Weight } \\
\text { gain }\end{array}$ \\
\hline Diet $^{1}$ & Day 0 & Day 30 & Period & Day 60 & Period & Total & Day 100 & Period & Total \\
\hline \multicolumn{10}{|l|}{$\mathrm{C}$} \\
\hline Mean & 18.3 & 35.0 & 16.7 & 57.8 & 22.8 & 39.5 & 95.8 & 38.0 & 77.5 \\
\hline$\pm \mathrm{SD}$ & 1.78 & 3.96 & 2.82 & 5.26 & 2.46 & 4.65 & 5.86 & 3.26 & 5.60 \\
\hline Index $\%$ & 100 & 100 & 100 & 100 & 100 & 100 & 100 & 100 & 100 \\
\hline \multicolumn{10}{|l|}{ DAB } \\
\hline Mean & 18.1 & 35.2 & 17.1 & 57.5 & 22.3 & 39.4 & 94.4 & 36.9 & 76.3 \\
\hline$\pm \mathrm{SD}$ & 1.64 & 3.38 & 2.41 & 5.06 & 2.26 & 4.14 & 7.64 & 5.06 & 7.56 \\
\hline Index $\%$ & 98.9 & 100.6 & 102.4 & 99.5 & 97.8 & 99.7 & 98.5 & 97.1 & 98.5 \\
\hline \multicolumn{10}{|l|}{ GAG } \\
\hline Mean & 18.0 & 33.1 & 15.1 & 54.8 & 21.7 & 36.8 & 95.0 & 40.2 & 77.0 \\
\hline$\pm \mathrm{SD}$ & 1.57 & 4.57 & 4.47 & 6.91 & 3.23 & 6.41 & 6.22 & 3.27 & 5.70 \\
\hline Index $\%$ & 98.4 & 94.6 & 90.4 & 94.8 & 95.2 & 93.2 & 99.2 & 105.8 & 99.3 \\
\hline \multicolumn{10}{|l|}{ PAG } \\
\hline Mean & 17.8 & 34.4 & 16.6 & 57.7 & 23.3 & 39.9 & 95.6 & 37.9 & 77.8 \\
\hline$\pm \mathrm{SD}$ & 1.81 & 4.83 & 3.81 & 8.12 & 4.04 & 7.03 & 14.1 & 8.85 & 13.1 \\
\hline Index $\%$ & 97.3 & 98.3 & 99.4 & 99.8 & 102.2 & 101.0 & 99.8 & 99.7 & 100.4 \\
\hline
\end{tabular}

1) $\mathrm{C}$ - control diet

$\mathrm{DAB}$ - dried surface amaranth biomass

$\mathrm{GAG}$ - ground amaranth grain

PAG - popped amaranth grain 
Total consumption of the diet was $2142 \mathrm{~kg}$ in group C, $1955 \mathrm{~kg}$ in experimental group fed DAB, $1733 \mathrm{~kg}$ in group fed GAG, and $1961 \mathrm{~kg}$ in group fed PAG. Average consumption of the diet per animal and day was $2.14 \mathrm{~kg}$ in group C, 2.12, 1.89 , and $1.96 \mathrm{~kg}$ in the other groups DAB, GAG and PAG, respectively. Feed conversion in the groups C, DAB, GAG, and PAG was 2.76, 2.78, 2.45, and $2.52 \mathrm{~kg}$, respectively.

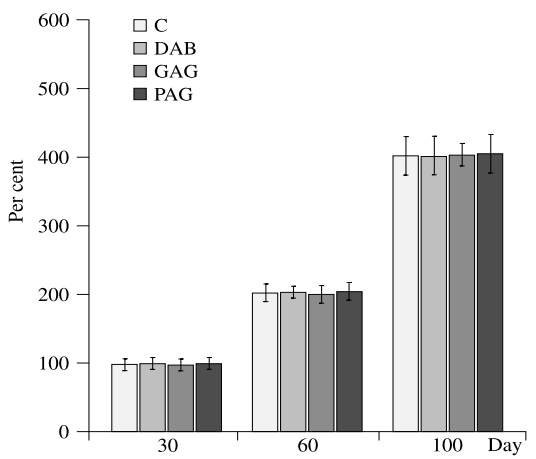

Fig. 1. Relative growth rate of fattened pigs

It follows from the results of biochemical analysis of blood plasma in all groups of pigs that most of investigated parameters ranged within physiological values as given by Tlučhoř (2001). The values of ALT were below the reference limit before the beginning and after the end of the experiments (Table 4). AST activity decreased with the increasing age of the animals in all the groups; the differences were highly significant in the control group $(P<0.01)$. The decline (within physiological limits) in triglyceride levels $(\mathrm{P}<$ $0.01)$ in group $\mathrm{DAB}$ and increased total cholesterol levels in group GAG $(P<0.05)$ were recorded. HDL cholesterol levels were increased in groups $\mathrm{C}$ and GAG $(P<0.01)$ in contrast to group DAB animals with decreased concentrations $(P<0.05)$.

Phosphorus levels during the entire course of the experiment were at the upper limit and manganese levels were at the lower limit of the reference ranges.

One piglet from group GAG was excluded from the experiment because of the iliac joint luxation on day 14 and another piglet with diagnosed endocarditis et pericarditis acuta from group DAB on day 22. Dwarfism syndrome was recorded in one piglet from group PAG. Another piglet with signs of chronic respiratory disease ingested less feed from day 58 to the end of the experiment. No clinical signs of a disease were observed in the other animals.

Appropriate hygienic conditions were maintained in the animal facilities during of the entire experimental period. Average temperatures recorded in the morning and in the evening in the stable were $21.0 \pm 2.2{ }^{\circ} \mathrm{C}\left(17.1\right.$ to $\left.24.9{ }^{\circ} \mathrm{C}\right)$ and $22.0 \pm 2.2{ }^{\circ} \mathrm{C}(16.8$ to $26.2^{\circ} \mathrm{C}$ ), respectively. Average relative humidity recorded in the morning and in the evening was $57.6 \pm 6.4 \%$ (44.6 to $71.3 \%$ ), and $56.8 \pm 6.1 \%$ (47.4 to $66.7 \%)$, respectively.

\section{Discussion}

Investigation was carried out under conditions providing objective assessment of the impact of respective diets on selected parameters of growth efficiency and health, including biochemical characteristics. In all groups, the sex of animals and their weight uniformity at the beginning of the trial (variance coefficient ranged between 8.8 and $10.1 \%$ ) were considered. Nutrient content (Table 2) in respective diets was almost identical. It follows that the feed rations were isocaloric and isoproteinic. The content of nitrogenic compounds was slightly increased in the control diet. The ratio between lysin and metabolizable energy concentration was particularly well balanced $\left(0.814\right.$ to 0.831 g. $\left.\mathrm{MJ}^{-1}\right)$.

Dried surface amaranth biomass was tested since it contains relatively high levels of nitrogenous compounds (14.3\%) and high concentrations of linoleic acid (15.1 or $4.0{\left.\mathrm{~g} . \mathrm{kg}^{-1}\right)}^{-1}$ in comparison with dried surface biomass of alfalfa (Zeman et al. 1995). Because of antinutrient substances present in amaranth grain (Corre a et al. 1986; Imeri et al. 1987), heat treating by popping $\left(30 \mathrm{~s}\right.$ at $\left.160^{\circ} \mathrm{C}\right)$ was used in one of the groups (PAG).

As confirmed by growth efficiency and health status of pigs (Tables 3 and 4), it is possible to successfully use diets without animal protein for fattened pigs, i.e. diets containing only 


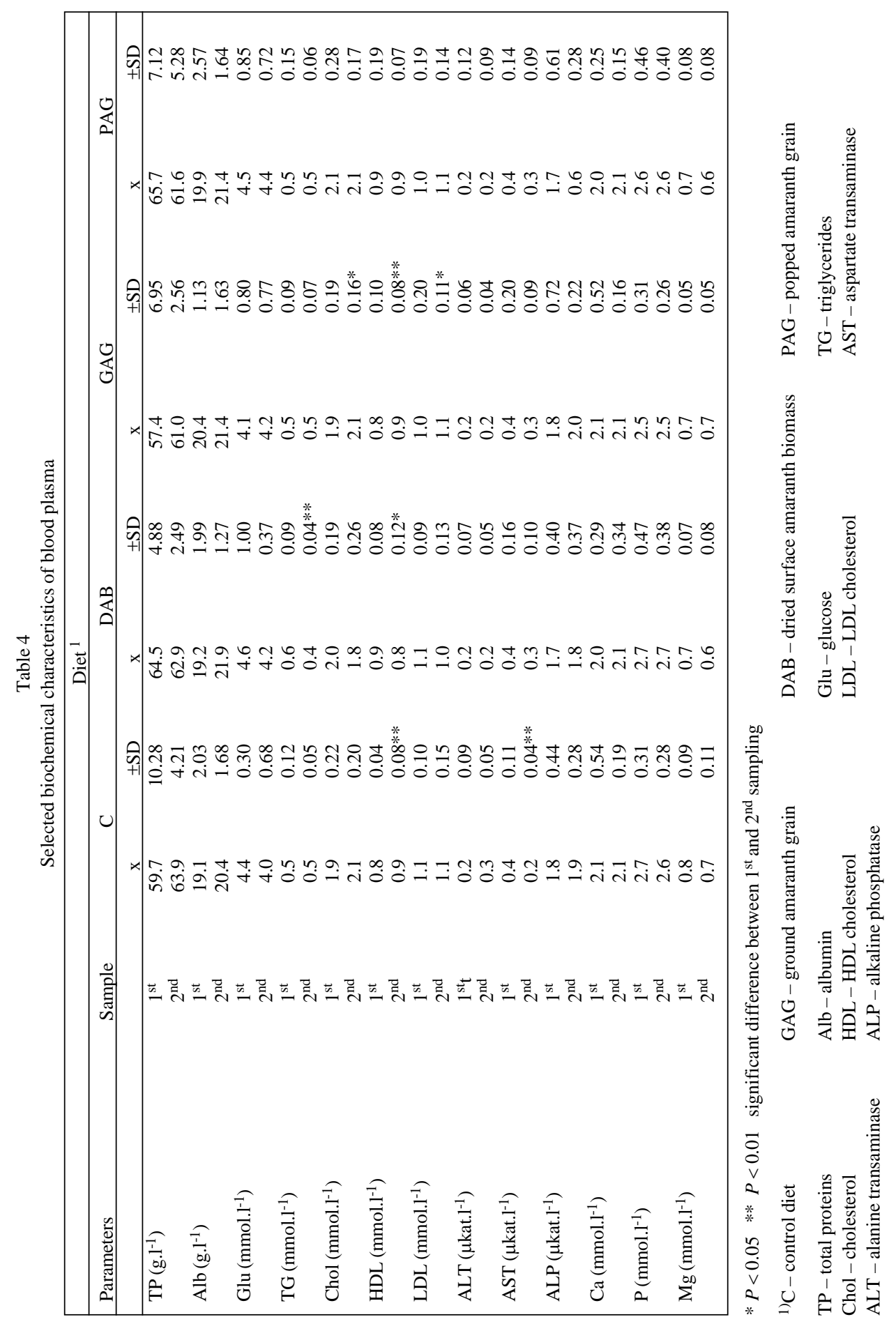


plant protein. The results expressed as the rate of live body weight gains, are even more notable, as they were obtained with the use of identical diet in each group of pigs during the entire experiment (pre-fattening, fattening stages I, and II), although the requirements for nutrients of the respective body mass categories of pigs are different (Ši i meč ek et al. 1993).

The differences in average daily weight gain between control and experimental groups were not significant. However, differences were observed in distinct periods of the experiment. In the first phase of the experiment (30 days), the highest daily weight gain of $0.57 \mathrm{~kg}$ was recorded in group DAB. From day 31 to 60 and from day 61 to 100 , the highest daily weight gains were recorded in groups PAG and GAG $(0.78$ and $1.01 \mathrm{~kg})$, respectively (Table 3). Similar results were obtained by van Lu nen et al. (2003) who included 10 to $30 \%$ extruded soy in ad libitum fed grower and finisher diets for pigs. It can be expected that provided the requirements for concentrations of nutrients and energy in the given phases of fattening and ad libitum feeding are met, pig growth intensity would be even higher.

Comparison of the diets tested in the present study documented a different daily intake and growth efficiency expressed by feed conversion per $\mathrm{kg}$ of the weight gain. Particularly in groups GAG and PAG with a lower daily feed consumption (1.89 and $1.96 \mathrm{~kg}$, respectively), feed conversion was higher (by 12.2 and $9.6 \%$, respectively) compared with the control group. It is remarkable that the growth efficiency was higher in group fed GAG diet compared with group PAG. The results obtained in our study did not confirm adverse effects of antinutrient substances in non-heat-treated amaranth grain (GAG). Imeri et al. (1987) give data concerning the presence of a trypsin inhibitor, phenols, tannin, saponins, and phytohaemagglutinins in amaranth.

During the course of the experiment, health status of pigs was assessed both by clinical examination and biochemical analysis of blood plasma. No clinically manifested disease or mortality related to the used diet was recorded during the experiment. It gives an evidence of a good health status of the pigs which was also confirmed by detected biochemical plasma parameters. Optimal microclimatic conditions maintained in animal facilities which is one of important prerequisites for effective nutrient conversion, definitely contributed to good health and production efficiency. Although two animals had to be excluded from the experiments because of acute alteration of the health status (luxation, endocarditis), partial data on the weight gains and feed consumption was included in the calculations. Low weight gain $(0.53 \mathrm{~kg}$ per day) and lower live body weight of a gilt from group PAG at the end of the experiment reflected exacerbation of a latent respiratory tract infection.

It can be concluded from the presented results that amaranth used in the diets in the form of both grain and dried surface biomass is a source of nutrients adequate to the components of animal origin which have been prohibited. Considering high biological value of amaranth protein, favourable amino acid composition and dietary fibre contents, it can be presumed that amaranth inclusion in feed diets for fattened pigs may partially solve the problem of animal protein replacement in the diets for monogastric animals. Moreover, it can be expected that high contents of lipids, essential fatty acids, particularly linoleic acid and squalen may be effective in wholesome pork production by modification of fatty acid composition.

\section{Vliv amarantu na růstové schopnosti a zdraví výkrmových prasat}

Cílem pokusu bylo ověřit u prasat produkční účinnost tř́i diet s obsahem $10 \%$ amarantu při použití stejné krmné směsi pro celé období výkrmu, zhodnotit vliv na vybrané ukazatele metabolismu a zdraví proti kontrolní dietě s obsahem živočišné bílkoviny. Pokusné skupiny a kontrolní skupina zvířat $(\mathrm{n}=10,5$ vepříků +5 prasniček) byly semiadlibitně krmeny krmnými směsmi s obsahem sušené nadzemní biomasy amarantu nebo neošetř̌eným či tepelně ošetřeným zrnem popováním, resp. směsí s obsahem masokostní 
moučky od živé hmotnosti 18 kg po dobu 100 dní. Mezi pokusnými zviŕaty a kontrolní skupinou nebyl zjištěn statisticky významný rozdíl v přírůstku živé hmotnosti. Nejvyšší denní přírůstek byl u zvírat krmených směsí $\mathrm{s}$ tepelně ošetřeným amarantem $(0,78 \mathrm{~kg})$ a nejefektivnější konverze krmiva byla u skupiny s tepelně neošetřeným zrnem $(2,45 \mathrm{~kg})$. Hodnoty vybraných biochemických ukazatelů se pohybovaly $\mathrm{v}$ rozsahu fyziologického rozmezí.

\section{Acknowledgements}

This work was supported by the Ministry of Agriculture of the Czech Republic, grant No. 0002716201. The authors wish to thank ing. J. Zajíc from Univit s.r.o., Olomouc, Czech Republic, for valuable recommendations and help concerning compositions of the diets and are grateful to AMR Amaranth a.s., Hradec Králové, Czech Republic, for providing us with amaranth.

\section{References}

ACAR, N, VOHRA, P, BECKER, R, HANNERS, GD, SAUNDERS, RM 1988: Nutritional evaluation of grain amaranth for growing chickens. Poultry Sci 67: 1166-1173

ANDRASOFSZKY, E, SZÖCZ, Z, FEKETE, S, JELENITS, K 1998: Evaluation of the nutritional value of the amaranth plant. I. Raw and heat-treated grain tested in experiments on growing rats. Acta Vet Hung 46: 47-59 ANONYMOUS: Notice No. 194/1996, Annex 3, Ministry of Agriculture of the Czech Republic (in Czech)

ANONYMOUS: White paper on food safety COM 719 final. Translation of the document. White book on food safety. VÚZE Prague, 2000a, ISBN 80-85898-81-0, 52 p. (in Czech)

ANONYMOUS: Notice No. 451/2000b, Annex 20, Ministry of Agriculture of the Czech Republic (in Czech)

BRESSANI, R, CONZALES, JM, ZUNIGA, J, BREUNER, M, ELIAS, LG 1987: Yield of amaranth grain representing four species. J Sci Food Afr 38: 347-356

CARLSSON, R 1979: Quantity and quality of amaranthus from plants on temperate, cold and hot and subtropical climates - A review. In: Proc. of Second Amaranth Conference, Rodale, Emmaus, Pennsylvania, USA, ISBN 087-8573-275, pp. 48-58

CORREA, AD, JOKL, L, CARLSSON, R 1986: Chemical constituens, in vitro protein digestibility, and presence of antinutritional substances in amaranth grains. Arch Latinoamer Nutr 36: 319-326

HERZIG, I 2001: Replacement of animal meat-and-bone meals with amaranth. Krmivářství 3: 37-38 (in Czech)

HERZIG, I, PÍSAŘíKOVÁ, B, DIBLÍKOVÁ, I, SUCHÝ, P 2001: Iodine concentrations in porcine blood, urine and tissues after a single dose of iodised oil. Vet Med Czech 46: 153-159

IMERI, A, FLORES, R, ELIAS, L, BRESSANI, R 1987: The effect of processing and supplementation with amino acids on the protein quality of amaranth (Amaranthus caudatus). Arch Latinoamer Nutr 37: 160-173

JAROŠOVÁ, J, MICHALOVÁ, A, VAVREINOVÁ, S, MOUDRÝ, J 1997: Cultivation and use of amaranth. Methods for Practice in Agriculture. UZPI Praha, ISBN 80-7271-042-7, 37 p. (in Czech)

KARAKOZ, A 1968: Research in animal husbandry. SVPL Bratislava, 352 p. (in Slovak)

MATOUŠKOVÁ, O, CHALUPA, J, CÍGLER, M, HRUŠKA, K 1992: STAT Plus - user manual. Veterinary Research Institute Brno, 168 p. (in Czech)

POND, WG, LEHMANN, JW 1989: Nutritive value of a vegetable amaranth cultivar for growing lambs. J Anim Sci 67: 3036-3039

SOMMER, A 2003: Soy in animal nutrition. Krmivářství 4: 1-4 (in Slovak)

SZELÉNYI-GALÁNTAI, M, ZSOLNAI-HARSZI, I 1992: Chemical and biological investigation of some seeds of the amaranth species and improvement of their protein utilisation by supplementation of maize and wheat. Allatten Takarm 41: 337-348 (in Hungarian)

ŠIMEČEK, K, ZEMAN, L, HEGER, J 1993: Nutrient requirement and tables of nutritional values of pig feeds. ČAZV Pohořelice, ISBN 80-901598-4-2, 78 p. (in Czech)

TILLMAN, PB, WALDROUP, PW 1987: Effects of feeding extruded grain amaranth to laying hens. Poultry Sci 66: $1698-1701$

TLUČHOŘ, V 2001: Evaluation of biochemical parameters in veterinary medicine from the standpoint of an individual and a herd. Krmivárství 5: 18-20 (in Czech)

VAN LUNEN, TA, HURNIK, D, JEBELIAN, V 2003: Growth performance, carcass quality and fatty acid composition of pigs fed diets containing extruded soybeans. Can J Anim Sci 83: 45-52

ZEMAN, L, ŠIMEČEK, K, KRÁSA, A, SIMEK, M, LOSSMANN, J 1995: Tables of nutritional values of feeds. VÚVZ Pohořelice, ISBN 80-901598-3-4, 465 p. (in Czech) 